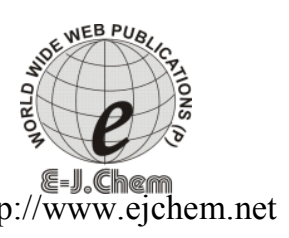

\title{
Characterization of Fly Ash Generated from Matla Power Station in Mpumalanga, South Africa
}

\author{
OLUSHOLA S. AYANDA ${ }^{1 *}$, OLALEKAN S. FATOKI ${ }^{1}$, FOLAHAN \\ A. ADEKOLA ${ }^{2}$, AND BHEKUMUSA J. XIMBA ${ }^{1}$ \\ ${ }^{1}$ Department of Chemistry, Faculty of Applied Sciences, Cape Peninsula University of \\ Technology, P.O. Box 1906, Bellville, South Africa \\ ${ }^{2}$ Department of Chemistry, University of Ilorin, P.M.B. 1515, Ilorin, Nigeria \\ osayanda@gmail.com
}

Received 05 November 2011; Accepted 7 January 2012

\begin{abstract}
In this study, fly ash was obtained from Matla power station and the physicochemical properties investigated. The fly ash was characterized by $\mathrm{x}-$ ray fluorescence, x-ray diffraction, scanning electron microscopy, and inductively coupled plasma mass spectrometry. Surface area, particle size, ash and carbon contents, $\mathrm{pH}$, and point of zero charge were also measured. The results showed that the fly ash is alkaline and consists mainly of mullite $\left(\mathrm{Al}_{6} \mathrm{Si}_{2} \mathrm{O}_{13}\right)$ and quartz $\left(\mathrm{SiO}_{2}\right)$. Highly toxic metals $\mathrm{As}, \mathrm{Sb}, \mathrm{Cd}, \mathrm{Cr}$, and $\mathrm{Pb}$ as well as metals that are essential to health in trace amounts were also present. The storage and disposal of coal fly ash can thus lead to the release of leached metals into soils, surface and ground waters, find way into the ecological systems and then cause harmful effect to man and its environments.
\end{abstract}

Keywords: Coal; Matla power station; Fly ash; Heavy metals; Characterization.

\section{Introduction}

Fly ash (FA) is the by-product of coal combustion process for energy generation, and is recognized as an environmental pollutant. Because of environmental problem of FA, a good deal of work and applications on the utilization of FA has been undertaken ${ }^{1-7}$. FA consists of fine, powdery particles that are predominantly spherical in shape, either solid or hollow, and mostly glassy (amorphous) in nature. The carbonaceous material in FA is composed of angular particles ${ }^{8}$. The specific gravity of FA usually ranges from 2.1 to 3.0 , while its specific surface area may range from 170 to $1000 \mathrm{~m}^{2} / \mathrm{kg}$. The color of FA can vary from tan to gray to black, depending on the amount of unburned carbon in the ash'. The lower the carbon content, the lighter the FA color. Lignite or sub-bituminous fly ashes are usually light tan to buff in color, indicating relatively low amounts of carbon as well as the presence of some lime or calcium. Bituminous fly ashes are usually shade of gray, with the lighter 
shades of gray generally indicating a higher quality of ash. The chemical properties of FA are determined by the type of the coal burned and the techniques used for handling and storage. There are basically four types of coal, each of which varies in terms of its heating value, its chemical composition, ash content, and geological origin. They are anthracite, bituminous, sub bituminous, and lignite. FA is also sometimes classified according to the type of coal from which the ash was derived. The principal components of bituminous coal FA are silica, alumina, iron oxide, and calcium, with varying amounts of carbon. Lignite and sub bituminous coal fly ashes are characterized by higher concentrations of calcium and magnesium oxide and reduced percentages of silica and iron oxide, as well as lower carbon content, compared with bituminous coal fly ash ${ }^{10}$.

Heavy metals detected in the FA can exhibit a broad range of toxic effects to humans, terrestrial and aquatic life and plants. These elements cannot be broken down or destroyed in the environment. They can, however, change from one form to another. FA may also introduce large quantities of heavy metals into the localized area and the heavy metals can also enter the aquatic environment and thus led to steady state back ground level in aquatic environment. Leached heavy metals from FA are hazardous to the environment because of their contribution in the formation of toxic compounds. This can lead to health, environmental and land-use problems ${ }^{11,12}$.

The aim of this study is therefore to carry out a comprehensive characterization of fly ash obtained from Matla power station, Mpumalanga, South Africa and to examine the composition of heavy metals that may be detrimental to human health and the environments.

\section{Experimental}

\section{Study Area}

The FA used in this present study was obtained from Matla power station situated approximately $30 \mathrm{~km}$ from Secunda in Mpumalanga, South Africa. The power station was the first of the giant $3600 \mathrm{MW}$ coal-fired power stations to be commissioned during the 1980 's and was fully operational in July $1983^{13}$.

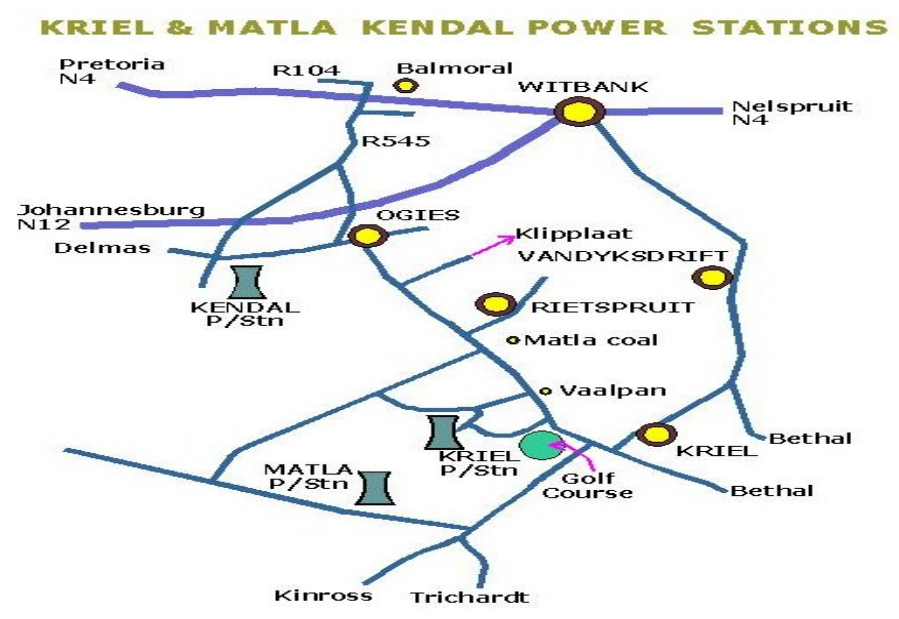

Figure 1. Map of Matla power station ${ }^{14}$. 
Matla is one of a few power stations in the world with a concrete boiler house superstructure, giving it an outward appearance very different from other power station in South Africa ${ }^{13}$.

\section{Laboratory Methods}

The x-ray fluorescence (XRF) and X-ray diffraction (XRD) analysis of Matla FA was carried out by the use of Philips PW1480 wavelength dispersive XRF spectrometer with a dual target $\mathrm{Mo} / \mathrm{Sc}$ x-ray tube and PANanalytical PW 3830 diffractometer, respectively. Inductively coupled plasma mass spectrometry (ICP-MS) was used to analyze the concentration of heavy metals present in the fly ash, the sample was prepared using Nitric acid - hydrogen peroxide digestion method and the filtrate analysed by ICP-MS (Agilent 7700). Other investigation include $\mathrm{pH}$, point of zero charge (PZC), particle size, surface area, ash and carbon contents and scanning electron micrograph (SEM).

\section{Results and Discussion}

Physicochemical Properties of Matla Fly Ash

The physicochemical characterization of Matla FA is as shown in Table 1 while the SEM is presented in Fig. 2.

Table 1. Physicochemical properties of Matla FA.

\begin{tabular}{|c|c|}
\hline Characteristics & Results \\
\hline $\mathrm{pH}$ & 10.70 \\
\hline PZC & 12.17 \\
\hline Particle size & $0.6-26.2 \mu \mathrm{m}$ \\
\hline Surface area & $1.06 \mathrm{~m}^{2} / \mathrm{g}$ \\
\hline Ash content & $97.4 \pm 0.14 \%$ \\
\hline Carbon content & $1.54 \%$ \\
\hline
\end{tabular}

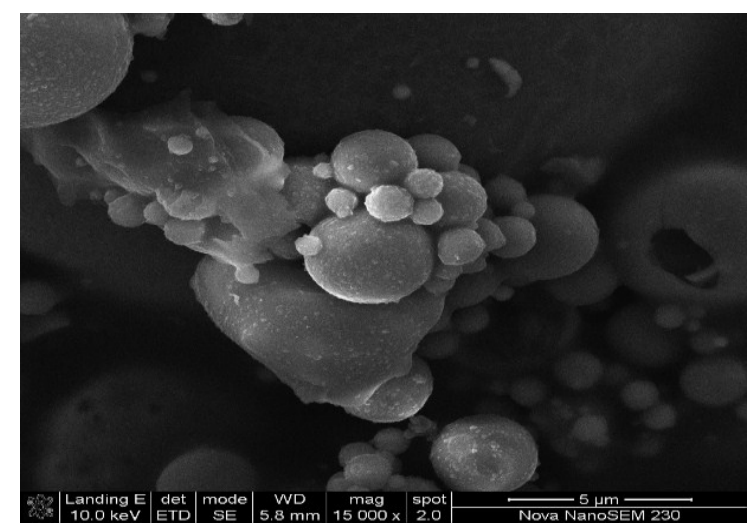

Figure 2: SEM of Matla FA. 
The SEM of FA showed that the particles of FA are spheres of various size distributions. Table 1 indicated that the particle size of FA ranges from $0.6-26.2 \mu \mathrm{m}$. The $\mathrm{pH}$ and PZC values which are 10.70 and 12.17 , respectively showed that Matla FA is alkaline with a ash content, carbon content and surface area of $97.4 \pm 0.14 \%, 1.54 \%$ and $1.06 \mathrm{~m}^{2} / \mathrm{g}$, respectively.

\section{XRF Elemental Composition of Matla Fly Ash}

The chemical composition of FA is shown in Table 2 which has alkaline $\left(\mathrm{Na}_{2} \mathrm{O}+\mathrm{K}_{2} \mathrm{O}\right)$ of $1.31 \%$ and alkaline rare earth's $(\mathrm{CaO}+\mathrm{MgO})$ of $8.70 \%$. The major constituents are $\mathrm{SiO}_{2}$ $51.43 \%$ and alumina $30.93 \%$. $\mathrm{TiO}_{2}$ and $\mathrm{Fe}_{2} \mathrm{O}_{3}$ do not exceed 1.74 and $2.29 \%$ respectively. The FA sample also contains $\mathrm{MnO}, \mathrm{P}_{2} \mathrm{O}_{5}, \mathrm{SO}_{3}, \mathrm{Cr}_{2} \mathrm{O}_{3}$ and $\mathrm{NiO}$ at $0.02,1.08,0.54,0.02$ and 0.01 percent, respectively.

Table 2. Elemental composition of Matla FA.

\begin{tabular}{|l|l|}
\hline Oxides & wt $\%$ \\
\hline $\mathrm{SiO}_{2}$ & 51.43 \\
\hline $\mathrm{TiO}_{2}$ & 1.74 \\
\hline $\mathrm{Al}_{2} \mathrm{O}_{3}$ & 30.93 \\
\hline $\mathrm{Fe}_{2} \mathrm{O}_{3}$ & 2.29 \\
\hline $\mathrm{MnO}$ & 0.02 \\
\hline $\mathrm{MgO}$ & 1.95 \\
\hline $\mathrm{CaO}$ & 6.75 \\
\hline $\mathrm{Na}{ }_{2} \mathrm{O}$ & 0.54 \\
\hline $\mathrm{K}_{2} \mathrm{O}$ & 0.77 \\
\hline $\mathrm{P}_{2} \mathrm{O}_{5}$ & 1.08 \\
\hline $\mathrm{SO}$ & 0.54 \\
\hline $\mathrm{Cr} \mathrm{O}_{3}$ & 0.02 \\
\hline $\mathrm{NiO}$ & 0.01 \\
\hline $\mathrm{LOI}$ & 1.21 \\
\hline $\mathrm{Total}_{3} 99.28$ & \\
\hline
\end{tabular}

The loss of mass on ignition (LOI) was $1.21 \%$ while the ratio of $\mathrm{SiO}_{2} / \mathrm{Al}_{2} \mathrm{O}_{3}$ was 1.66 . The obtain result (Table 2) is similar to the result obtained by Gitari et al. ${ }^{15}$ who reported the XRF analysis of FA from two South African power plants (Arnot and Matla) and Vimlesh and Giri ${ }^{16}$ who reported the elemental concentration of FA generated from Parichha thermal power station in Jhansi, India. 


\section{XRD of Matla Fly Ash}

The diffractogram of FA is presented in Figure 3. The diffractogram showed that the FA consists mainly of crystalline minerals mullite $\left(\mathrm{Al}_{6} \mathrm{Si}_{2} \mathrm{O}_{13}\right)$ and quartz $\left(\mathrm{SiO}_{2}\right)$ with large characteristic peaks of quartz $\left(\mathrm{SiO}_{2}\right)$.

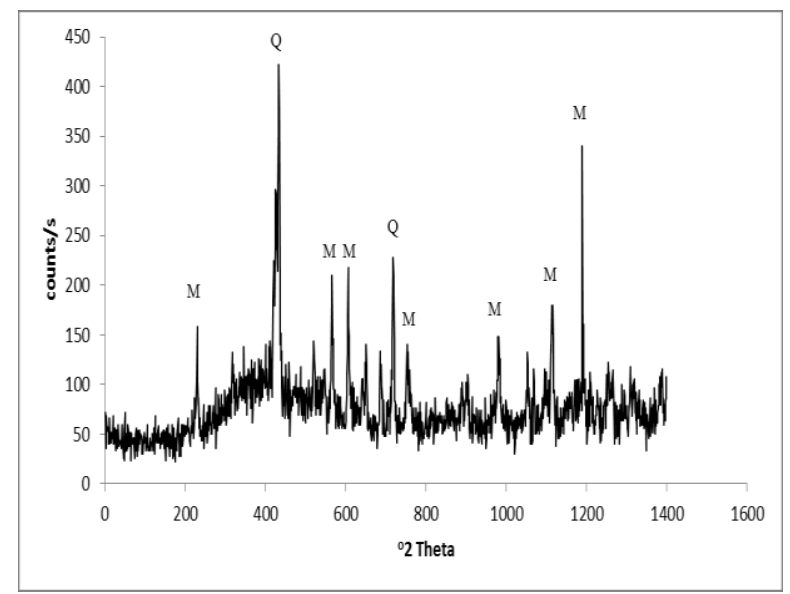

$\mathrm{M}$ - Mullite $\left(\mathrm{Al}_{6} \mathrm{Si}_{2} \mathrm{O}_{13}\right), \mathrm{Q}-$ Quartz $\left(\mathrm{SiO}_{2}\right)$

Figure 3. X-ray diffraction of FA.

The XRD analysis thus confirms the predominant alumina and silica composition of FA.

Heavy Metals in Fly Ash

The concentration of heavy metals analysed by ICPMS was presented in Table 3.

Table 3. ICPMS analysis of FA.

\begin{tabular}{|l|l|}
\hline Heavy metals & Conc. $($ ppm $)$ \\
\hline $\mathrm{As}$ & 16.61 \\
\hline $\mathrm{Cd}$ & 0.16 \\
\hline $\mathrm{Co}$ & 5.45 \\
\hline $\mathrm{Cr}$ & 72.97 \\
\hline $\mathrm{Cu}$ & 18.76 \\
\hline $\mathrm{Mn}$ & 148.10 \\
\hline $\mathrm{Mo}$ & 18.31 \\
\hline $\mathrm{Ni}$ & 13.94 \\
\hline $\mathrm{Pb}$ & 24.38 \\
\hline $\mathrm{Sb}$ & 0.54 \\
\hline $\mathrm{Se}$ & 8.88 \\
\hline $\mathrm{Sr}$ & 1696.00 \\
\hline $\mathrm{Ti}$ & 2003.00 \\
\hline $\mathrm{V}$ & 103.85 \\
\hline $\mathrm{Zn}$ & 20.03 \\
\hline
\end{tabular}


The Matla FA contained detectable concentrations of all the toxic and potentially toxic elements analysed for. Cobalt $(\mathrm{Co})$, copper $(\mathrm{Cu})$, iron $(\mathrm{Fe})$, manganese $(\mathrm{Mn})$, molybdenum (Mo), vanadium (V), titanium (Ti), Selenium (Se), strontium (Sr), and zinc ( $\mathrm{Zn}$ ) present are essential to health in trace amounts while arsenic (As), antimony ( $\mathrm{Sb})$, cadmium $(\mathrm{Cd})$, chromium $(\mathrm{Cr})$, and lead $(\mathrm{Pb})$ are harmful to health in excessive amounts. Heavy metals can readily be leached into waterways such as rivers, lakes and by dissolving in rain, thereby causing harmful effect on the environments and human health.

\section{Arsenic}

Arsenic is toxic to plants, animals and humans. Arsenic is carcinogenic to humans by both the oral and inhalation routes. Symptoms include vomiting, abdominal pain, fatigue, paresthesia, paralysis, diarrhea, garlic odor on breath, excessive salivation, headache, vertigo, kidney failure, progressive blindness, and mental impairment. Signs are mottled brown skin, hyperkeratosis of palms and soles, cutis edema, transverse striate leukonychia, perforation of nasal septum, eyelid edema, coryza, limb paralysis and reduced deep tendon reflexes while mental symptoms include apathy, anorexia and dementia.

\section{Antimony}

The toxic effects of antimony are lung diseases, skin irritation, heart problems, diarrhea, severe vomiting and stomach ulcers. Signs and symptoms include violent vomiting, diarrhea with mucus, hepatitis, hemoturia, irritability, laryngitis, tracheitis, cough, dyspnea, fatigue, neuritis, muscular aches, anorexia, nausea and constipation, headache, dizziness, and chest pain.

\section{Cadmium}

Cadmium poisoning can result in respiratory and gastrointestinal tracts irritation, vomiting / nausea, stomach cramps, diarrhea, tenesmus, kidney damage, liver injury (jaundice), fragile bones, and death.

\section{Chromium}

Chromium can accumulate in many aquatic species ${ }^{17}$. Chromium is corrosive, and allergic skin reactions readily occur following exposure. Damage to the kidney and liver has also been reported ${ }^{18}$.

\section{Lead}

The toxic effects of lead include damage to the kidneys, cardiovascular and nervous system. Signs and Symptoms include combinations of gastrointestinal complaints, hypertension, fatigue, hemolytic anemia, abdominal pain, nausea, arthralgias, headache, weakness, convulsions, irritability, constipation, weight loss, peripheral neuropathy, cognitive dysfunction, impotence, loss of libido, depression, depression of thyroid and adrenal function, chronic renal failure, and gout. Mental symptoms include restlessness, irritability, confusion, excitement, insomnia, anxiety, delusions, and disturbing dreams.

\section{Conclusion}

Experimental results showed that the major constituents of FA are $\mathrm{SiO}_{2}$ and $\mathrm{Al}_{2} \mathrm{O}_{3}$. It is alkaline and also consists of heavy metals that are detrimental to human health and the environments. The heavy metals are $\mathrm{As}, \mathrm{Sb}, \mathrm{Cd}, \mathrm{Cr}$, and $\mathrm{Pb}$. The storage and disposal of coal FA can thus lead to the release of leached metals into soils, surface and ground waters. The majority of these elements are able to build up in soils and sediment, and many are persistent 
and highly toxic to animals, humans and plants through air, water and soil uptake. In many countries, FA produced from coal combustion are utilised rather than disposed. Although this method can reduce the immediate leaching of heavy metals and other toxic chemicals, weathering and erosion over time may ultimately cause their release back to the environment.

\section{Acknowledgment}

Olushola S. Ayanda wishes to thank Cape Peninsula University of Technology, Cape Town, South Africa for the award of 2011 CPUT bursary to study D. Tech. Chemistry in the institution.

\section{Reference}

1. Al-Almoudi A, Maslehuddin M. Performance and correlation of the properties of fly ash, cement and concrete. Cement Concrete Res., 1996, 18, 253-60.

2. Temimi M, Camps JP, Lacquerbe M. Valorisation of fly ash in the cold stabilisation of clay materials. Resour Conser Recycl., 1995, 15, 219-34.

3. Barbieri L, Isabella I, Manfredini T, Querait I, Ma-Rincon J, Romero M. Design, obtainment and properties of glasses and glass-ceramics from coal fly ash. Fuel, 1999, $78,271-6$.

4. Verghese KT, Chaturvedi BK. Fly ash as fine aggregate in polyester based polymer composites. Cement Concrete Composites, 1996, 18, 105-8.

5. Viraraghavan T, Rao AKG. Adsorption of cadmium and chromium from wastewater by fly ash. J Environ Sci Health Part A, 1995, 26, 721- 53.

6. Weng $\mathrm{CH}$, Huang $\mathrm{CP}$. Treatment of metal industrial wastewater by fly ash and cement fixation. J Environ Eng., 1994, 120, 1470-87.

7. Musapatika ET, Onyango, MS, Aoyi O. Cobalt(II) removal from synthetic wastewater by adsorption on South African coal fly ash. S. Afr. j. sci., 2010, 106, 1-7.

8. Ozdemir O, Ersoy B, Celick MS. Separation of pozzolonic material from lignitic fly ash of Tuncbilek power station. International Ash Utilization Symposium, Center for Applied Energy Research, University of Kentucky, 2001, 1-8.

9. Kassim TA, Williams KJ. Environmental impact assessment of recycled wastes on surface and ground waters. Concepts; Methodology and Chemical analysis. SpringerVerlag Berlin, Heidelberg, 2005, 94.

10. Leman S. Removal of boron from waters using fly ash, M.Sc. Thesis, Submitted to the Graduate School of Engineering and Science of İzmir Institute of Technology, İZMIR, $2005,1-84$.

11. Baba A. Geochemical assessment of environmental effects of ash from Yatagan (MuglaTurkey) thermal power plant. Water Air Soil Pollut., 2003, 144, 3-18.

12. Mandal A, Sengupta D. Characterization of fly ash from coal-based thermal power station at Kolaghat-Possible environmental hazards. Indian J Environ Protect, 2002, 22, 885-91.

13. Eskom. Matla Power Station. http://www.eskom.co.za/c/article/43/matla-power-station/ Eskom Holdings SOC Limited, 2011a. (Accessed: 03/11/2011). 
14. Eskom. Matla Power Station Map. http://www.eskom.co.za/c/article/44/matla-powerstation-map/ Eskom Holdings SOC Limited, 2011b. (Accessed: 03/11/2011).

15. Gitari WM, Somerset VS, Petrik LF, Key D, Iwuoha E, Okujeni C. Treatment of acid mine drainage with fly ash: Removal and major, minor elements, SO4 and Utilization of the solid residues for wastewater treatment. Fuel, 2008, 87, 2450-2462.

16. Vimlesh K, Giri AK. Characterization of Fly Ash Generated from Parichha Thermal Power Station in Jhansi, India. E-Journal of Chemistry, 2011, 8, (1), 400-404.

17. Kimbrough DE, Cohen Y, Winer AM, Creelman L, Mabuni C. A critical assessment of chromium in the Environment. Critical Reviews in Environmental Science and Technology, 1999, 29, (1), 1-46.

18. USPHS. Toxicological profile on CD-ROM. Agency for Toxic Substances and Disease Registry. U.S. Public Health Service, 2005. 


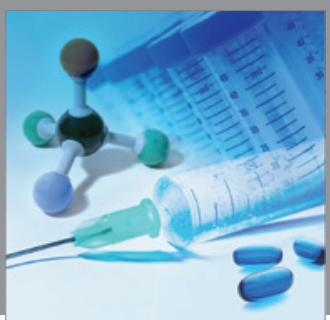

International Journal of

Medicinal Chemistry

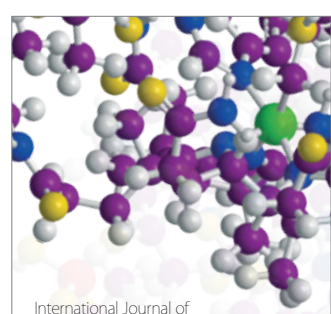

Carbohydrate Chemistry

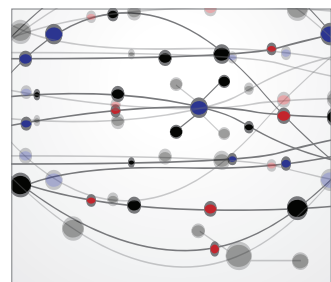

The Scientific World Journal
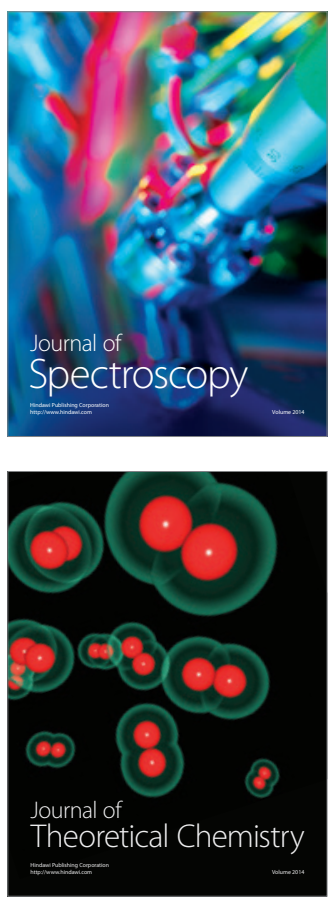
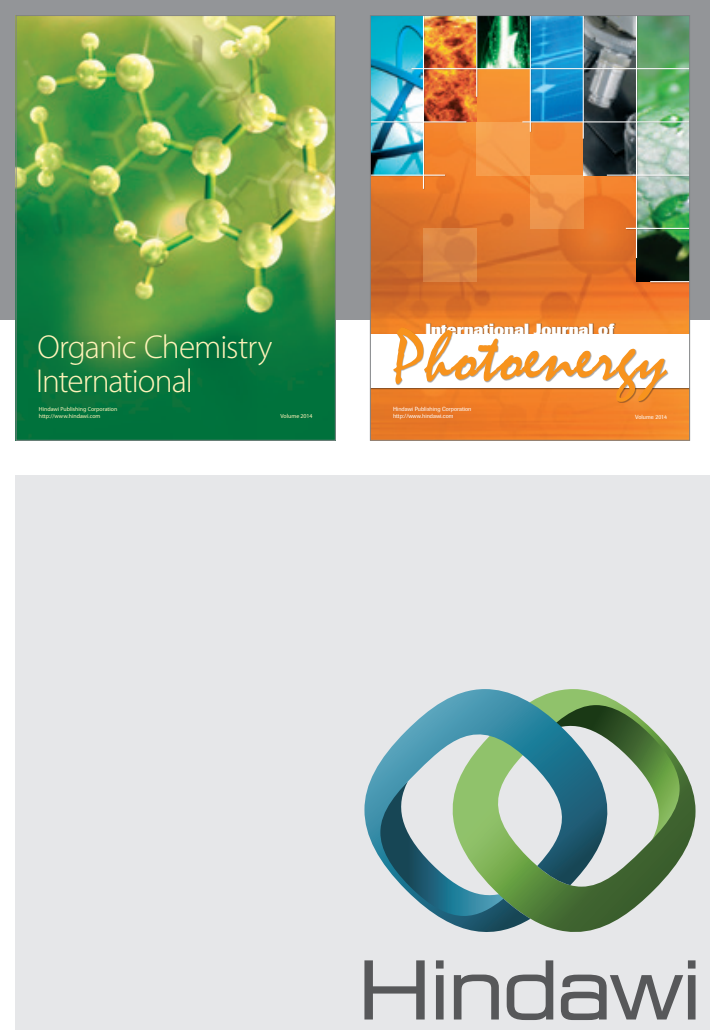

Submit your manuscripts at

http://www.hindawi.com
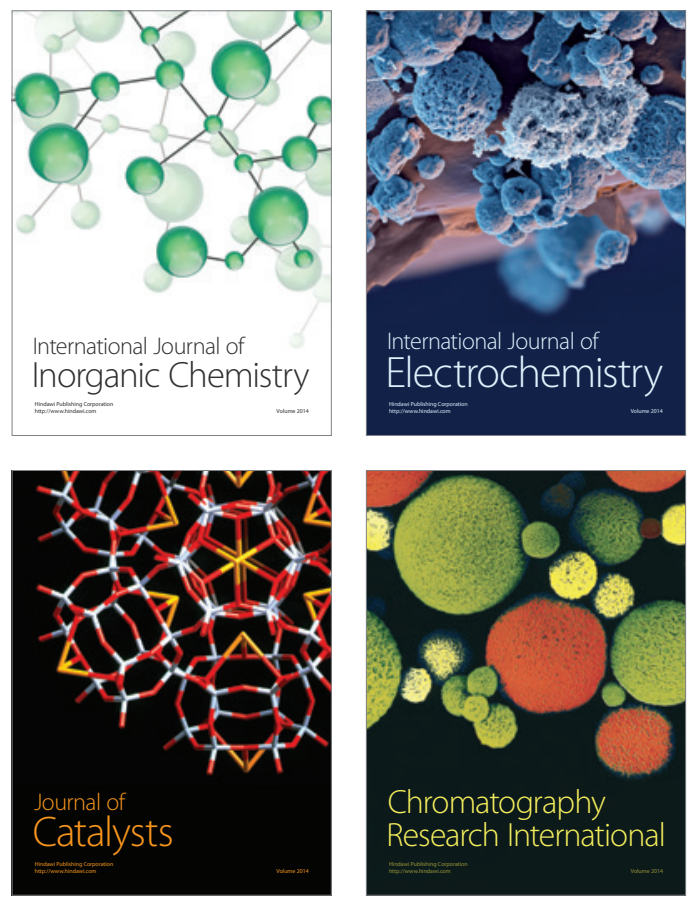
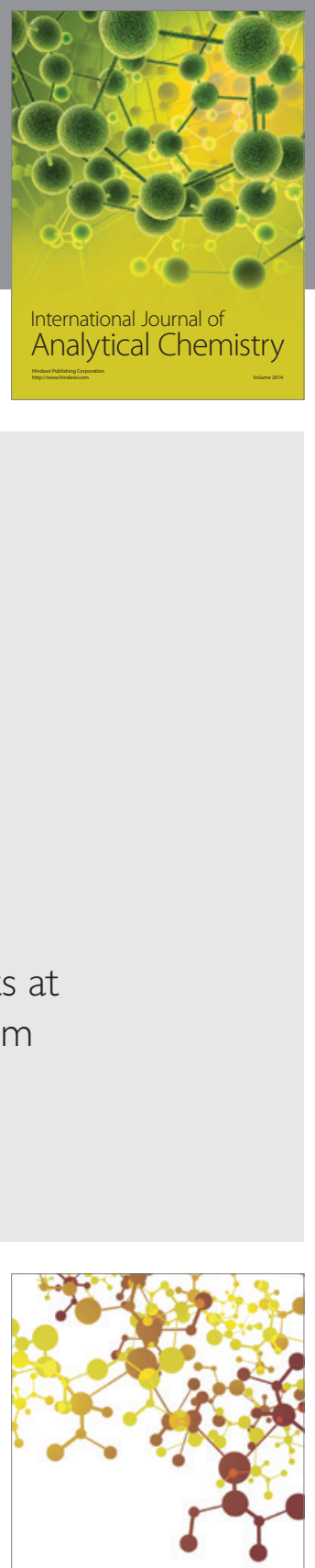

Journal of

Applied Chemistry
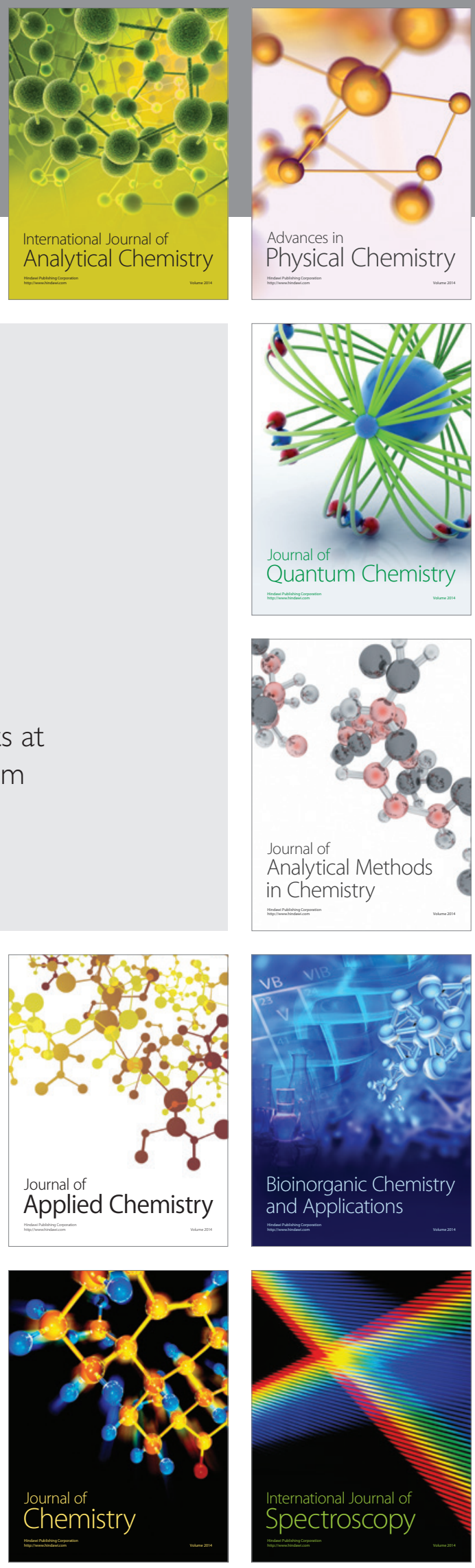